See discussions, stats, and author profiles for this publication at: https://www.researchgate.net/publication/236916465

\title{
New data on the endemic Patagonian long-clawed mouse Notiomys edwardsii (Rodentia: Cricetidae)
}

Article in Mammalia · December 2008

DOI: 10.1515/MAMM.2008.040

CITATIONS

19

4 authors, including:

Daniel Udrizar Sauthier

Instituto Patagónico Para el Estudio de los Ecosistemas Continentales

59 PUBLICATIONS 482 CITATIONS

SEE PROFILE

Guillermo D'Elía

Universidad Austral de Chile

136 PUBLICATIONS 2,013 CITATIONS

SEE PROFILE

Some of the authors of this publication are also working on these related projects:

Project FONDECYT 1100166 View project

Predator, prey and parasites dynamics. Space and Temporal variation. View project
365

Pablo Teta

Museo Argentino de Ciencias Naturales "Bernardino Rivadavia" 182 PUBLICATIONS 1,583 CITATIONS

SEE PROFILE 


\section{New data on the endemic Patagonian long-clawed mouse Notiomys edwardsii (Rodentia: Cricetidae)}

\author{
Ulyses F.J. Pardiñas ${ }^{1, \star}$, Daniel E. Udrizar \\ Sauthier ${ }^{1}$, Pablo Teta ${ }^{2}$ and Guillermo D'Elía ${ }^{3}$ \\ 1 Unidad de Investigación Diversidad, Sistemática y \\ Evolución, Centro Nacional Patagónico, Casilla de \\ Correo 128, 9120 Puerto Madryn, Chubut, Argentina, \\ e-mail: ulyses@cenpat.edu.ar \\ 2 Departamento de Ecología, Genética y Evolución, \\ Facultad de Ciencias Exactas y Naturales, Universidad \\ de Buenos Aires, Avenida Intendente Cantilo s/n, \\ Ciudad Universitaria, Pabellón II, $4^{\circ}$ Piso, C1428EHA \\ Buenos Aires, Argentina \\ ${ }^{3}$ Departamento de Zoología, Universidad de \\ Concepción and Centro de Investigación en \\ Ecosistemas de la Patagonia, Casilla 160-C, \\ Concepción, Chile \\ ${ }^{*}$ Corresponding author
}

\begin{abstract}
The monotypic Notiomys is the most poorly-known genus of Abrotrichini, a recently erected tribe of South American sigmodontine rodents. Based on a large sample, mostly recovered from owl pellets but including trapped individuals, we refine the known geographic distribution of this mouse (providing 20 new contemporary recording localities and four fossil occurrences), relate this to the principal Patagonian environmental units, add new data on the type locality of the species, and comment on its conservation status. In addition, we present a detailed external and craniodental description and provide data showing geographic variation of some skull features. Finally, we provide preliminary data on genetic variation (cytochrome $b$ gene sequences) that demonstrate the existence of a low degree of observed differentiation (ca. $0.7 \%$ ) between the populations analyzed.
\end{abstract}

Keywords: Abrotrichini; Argentina; Chelemys; Geoxus; Pearsonomys.

\section{Introduction}

Abrotrichines form a small group of genera of South American cricetid rodents. For many decades, abrotrichines were considered to be part of Akodontini; however, the use of molecular evidence and a reappraisal of morphologic variation promoted their separation and consolidation as a new tribe of Sigmodontinae (D'Elía et al. 2007). Within Abrotrichini two main clades are recognized, one constituted solely by the polytypic Abrothrix and the other including four long-clawed genera, Chelemys, Geoxus, Notiomys, and Pearsonomys (D'Elía et al. 2006).
Knowledge about abrotrichines is markedly uneven and is strongly biased towards Abrothrix (Liascovich et al. 1989, Spotorno 1992, Lozada et al. 1996, Smith et al. 2001, Pearson 1995). With the partial exception of Chelemys, the other genera of long-clawed mice remain poorly known. Current knowledge of the monotypic Notiomys, an endemic species of Argentinean Patagonia, is limited to scattered data on morphology and natural history and the compilation of recording localities (Pearson 1984, Reig 1987, Patterson 1992, Pardiñas and Galliari 1998, Teta et al. 2002, Martin and Archangelsky 2004).

Toward partially filling the gap in our knowledge of the long-clawed mouse Notiomys edwardsii Thomas 1890, the aim of the present study was to provide a description of its molar occlusal pattern, skull, stomach, and external morphology, and a preliminary assessment of its genetic variation. Based on our compilation of pertinent information, we restrict the location of the type locality of $N$. edwardsii; in addition, we expand its known geographic distribution through the addition of 20 contemporary and four fossil new recording localities. Finally, we discuss the association between this mouse and the main environmental units recognized for Patagonia, and comment on its conservation status.

\section{Materials and methods}

Most of the specimens studied were recovered from owl pellets. A fresh individual was found dead in the field and was prepared as skin and skeleton and tissues preserved in ethanol. We also studied four specimens housed in collections (Table 1). It is important to emphasize that in spite of intensive fieldwork using snap and Sherman traps in different places and different seasons where Notiomys edwardsii, as indicated by owl pellet analyses, is abundant, no specimen was trapped. Acronyms for institutions and collections mentioned in the text and tables are: BM, Natural History Museum of London, London, UK; CNP, Colección de Mamíferos del Centro Nacional Patagónico, Puerto Madryn, Chubut, Argentina; CNP-E, Colección de Materiales de Egagrópilas y afines "Elio Massoia" del Centro Nacional Patagónico, Puerto Madryn, Chubut, Argentina; LER.E, Laboratorio de Ecología de Roedores, Departamento de Ecología, Genética y Evolución, Facultad de Ciencias Exactas y Naturales, Universidad de Buenos Aires, Argentina; LIEB M, Laboratorio de Investigaciones en Evolución y Biodiversidad, Facultad de Ciencias Naturales Sede Esquel, Universidad Nacional de la Patagonia, Esquel, Chubut, Argentina, MACN, Museo de Ciencias Naturales "Bernardino Rivadavia", Buenos Aires, Argentina; and MVZ, Museum of Vertebrate Zoology, Berkeley, California, USA. 


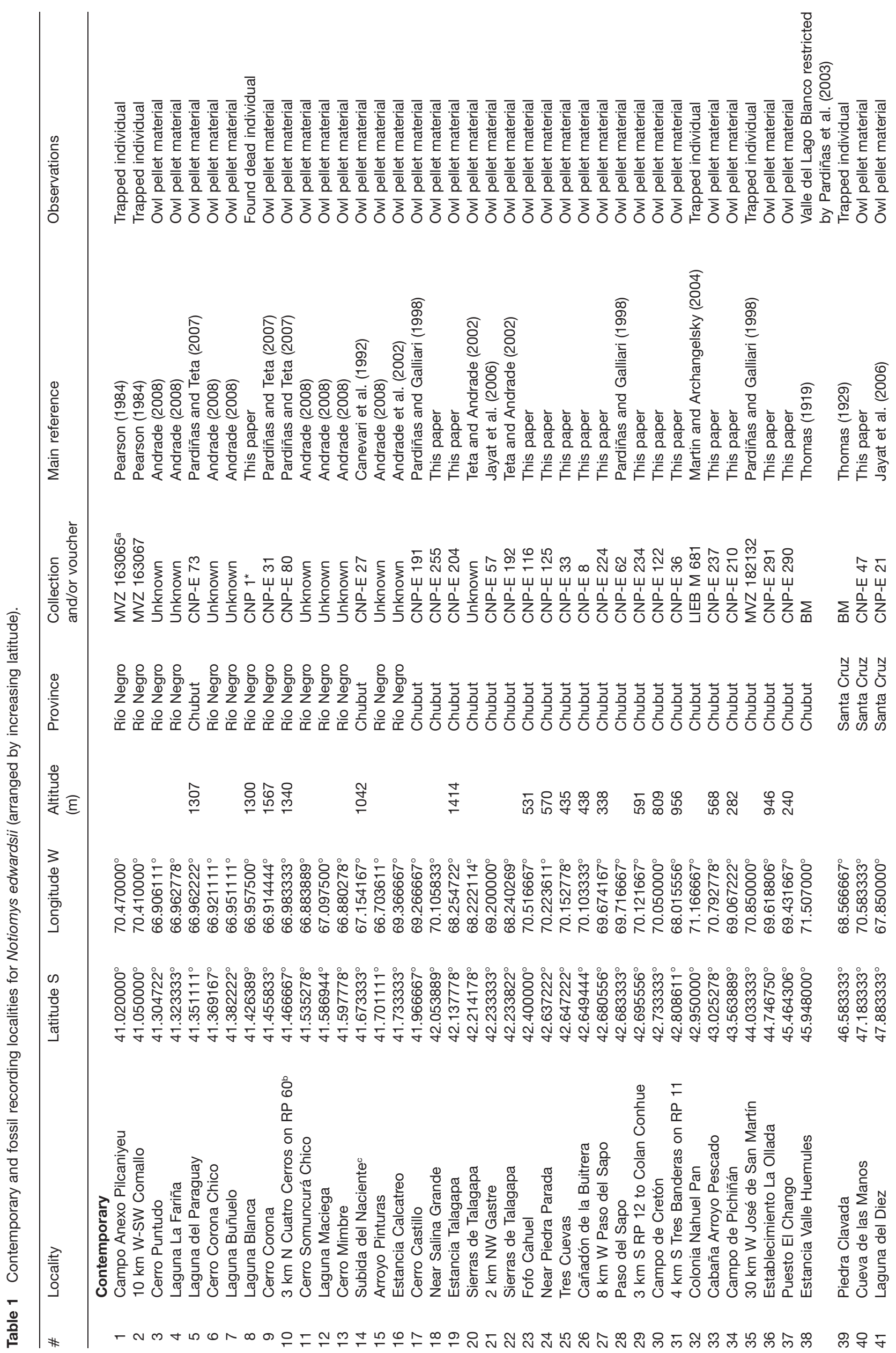




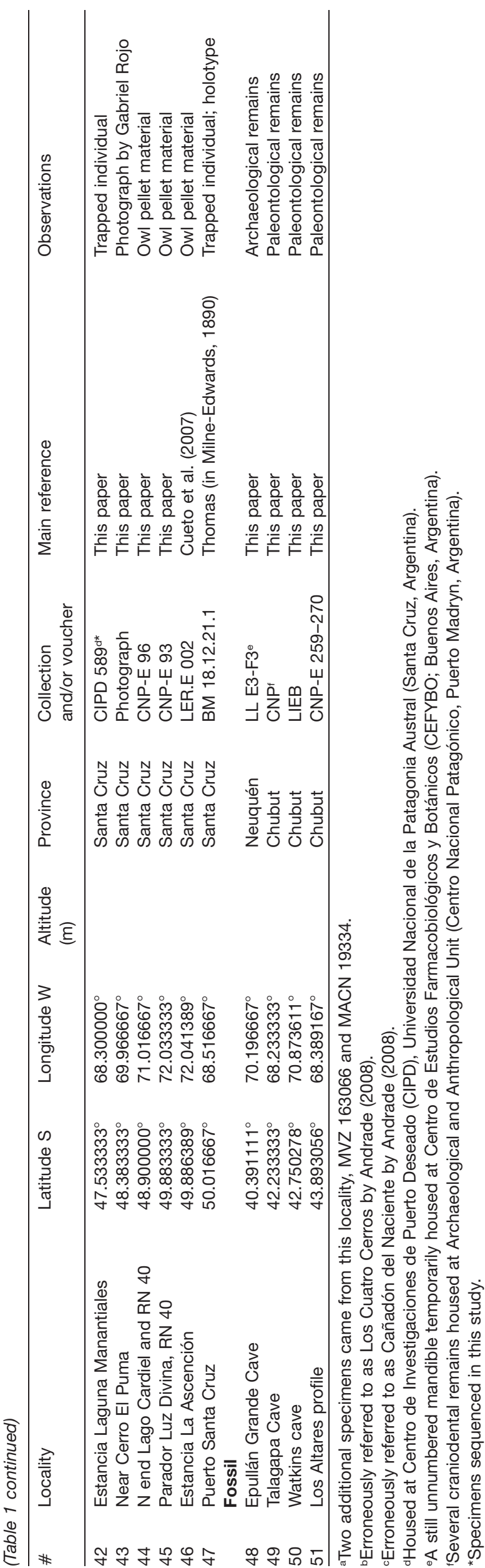

Morphological descriptions follow the concepts of Carleton and Musser (1989) and Patterson (1992) for cranial anatomy and Reig (1977) for molar occlusal structures. Standard external measurements were taken from specimen labels and the literature. Craniodental measurements were made using digital calipers and follow the definitions provided by Tribe (1996).

The analysis of genetic variation is based on 801-bp cytochrome $b$ (cyt b) sequences gathered from three specimens. One sequence was obtained from GenBank (U03537) and we obtained the other two (Table 1) following the protocol detailed in D'Elía and Pardiñas (2004) and deposited them with GenBank (EU416275 and EU416276). Sequences were aligned by eye with sequences from specimens of Chelemys, Geoxus, and Pearsonomys (U03533, U03531, AF108672) that were used as an outgroup. Reported sequence divergence values correspond to observed $(p)$ values calculated with PAUP* (Swofford 2000) ignoring those sites with missing data. The genealogy discussed was obtained by analysis of maximum parsimony (Farris 1982) instrumented as an exhaustive search in PAUP*. Clade support was assessed by 1000 bootstrap replicates with five replicates of random sequence addition each.

\section{Results and discussion}

\section{Notiomys Thomas 1890}

Type species Hesperomys (Notiomys) edwardsii Thomas, 1890

Remarks There is some confusion regarding the year of publication of this genus and species. Most authorities used 1890 (Osgood 1925, Gyldenstolpe 1932, Cabrera 1961, Musser and Carleton 2005). However, 1891 is the year printed on the cover of the "Mission Scientifique du Cap Horn 1882-1883. Tome VI. Zoologie. Premiére partie," the publication in which the names were proposed. Similarly, this publication is listed as 1891 in the "Catalogue of the books, manuscripts, maps and drawings in the British Museum (Natural History)" (1904 edition, L. Di Tommaso, personal communication). To add more uncertainty, Thomas (1929: 42) wrote in reference to Notiomys edwardsii "...species described by me in 1892." We follow here the traditional date used, but remark that this issue needs further research to be resolved.

Holotype BM 18.12.21.1, an adult individual, unknown sex, collected by Le Brun in December 1882.

Type locality "la Patagonie, au sud de Santa Cruz, vers le $50^{\circ}$ degré de latitude Sud" (Thomas in MilneEdwards 1890: A.25). It is interesting to reconstruct how this rodent captured in Santa Cruz province (continental Argentina) was finally reported as a new species in an account covering the region of Cape Horn. Several scientific expeditions were sent from France to observe the transit of Venus in 1882. Two of them focused on southern localities of South America, Santa Cruz and Cape Horn. The expedition to Santa Cruz was led by the naval officer Georges-Ernest Fleuriais (1840-1895) in the ship 
276 U.F.J. Pardiñas et al.: New data on Patagonian long-clawed Notiomys

Volage (Mouchez 1882). Le Brun (spelling according to Fleuriais 1882) or Lebrun (according to Milne-Edwards 1890) was the naturalist assigned to this expedition. Le Brun collected some specimens, including the holotype of Notiomys edwardsii, in an area around where the Volage crew carried out astronomical observations. The exact location of these places is not known, but likely they were not far from "Santa Cruz", at that time the only village in this large area, no more than a few shanties by Cañadón Misionero, a small creek with its mouth at $49^{\circ} 59^{\prime} \mathrm{S}$ and $68^{\circ} 33^{\prime}$ W. In 1884 Carlos Moyano was designated as the first governor of Santa Cruz territory; he selected "Santa Cruz" as the capital, but moved its placement approximately $4 \mathrm{~km}$ south, to another temporary creek (Cañadón del Quemado), approximately 4.5 miles downwater of the conjunction between the rivers
Santa Cruz and Chico (Moyano 1948). During the last century, the use of "Santa Cruz" declined and was replaced by Puerto Santa Cruz, with geographic coordinates at $50^{\circ} 01^{\prime} \mathrm{S}$ and $68^{\circ} 31^{\prime} \mathrm{W}$. Therefore, the "Santa Cruz" visited by Le Brun in 1882 and Puerto Santa Cruz are not the same place, although they are close to each other. Moreover, ambiguity regarding the exact place where Le Brun collected the holotype of $N$. edwardsii must be borne in mind. In this context and for taxonomic and nomenclatural purposes, the type locality of $N$. edwardsii must be restricted to Puerto Santa Cruz (province of Santa Cruz, Argentina), a proposition mentioned briefly by Pardiñas and Galliari (1998), and incorrectly transcribed by Musser and Carleton (2005: 1136). We note that, other than the holotype, no additional specimen is known from the type locality; the closest record-

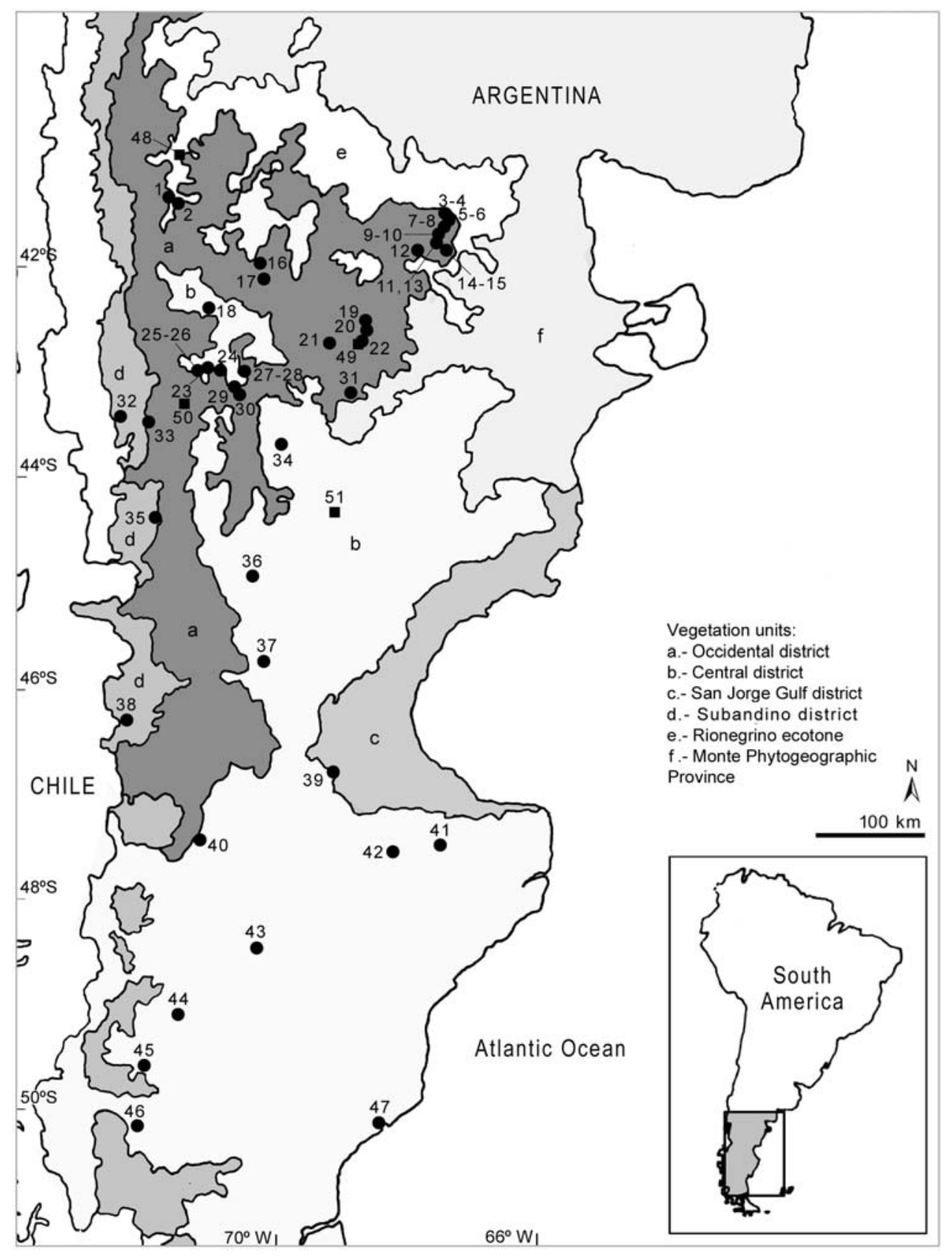

Figure 1 Recording localities for Notiomys edwardsii superimposed on the principal phytogeographic units that occur in Argentinean Patagonia. See Table 1 for reference numbers. 
ing locality to Puerto Santa Cruz is near Cerro El Puma, approximately $180 \mathrm{~km}$ to the northwest.

When the Fleuriais mission ended, Le Brun traveled by land to Punta Arenas (Chile) to meet the second French expedition to South America, commanded by Captain Louis-Ferdinand Martial, destined for Cape Horn (Martial 1888). All the zoological material collected by Le Brun in both French missions was finally studied and published by Milne-Edwards (1890), who invited Oldfield Thomas to describe the cricetids.

Distribution An exhaustive search of the literature and collections retrieved 47 contemporary recording localities for Notiomys edwardsii (Table 1; Figure 1), ranging from ca. $41^{\circ} \mathrm{S}$ to $50^{\circ} \mathrm{S}$ and encompassing the Argentinean provinces of Santa Cruz, Chubut, and Río Negro. One record based on material recovered from Galictis cuja scats from Quilquihue (Neuquén province, Argentina; Delibes et al. 2003) is dubious and can be discarded (A. Travaini personal communication).

Emended morphological diagnosis A member of the tribe Abrotrichini characterized by the following combination of traits: small size (head and body length ca. 80 $\mathrm{mm}$ ), short tail (ca. $40 \mathrm{~mm}$ ); head with bright orange spots on the rump sides; very small ears showing a tuft of contrasting white hairs; manus and pes dorsally covered by whitish-orange to white hairs; manus with welldeveloped sharp claws; pes with conspicuous inner and outer fringes of hairs; skull with shorted rostrum, broad amphoral interorbital region, rounded braincase and expanded zygomatic arches; nasals covering most of the rostrum and surpassing the anterior face of incisors, somewhat trumpeted; inconspicuous zygomatic notches; narrow and tall zygomatic plates without an upper free border, strongly flared with respect to sagittal plane and producing a wide infraorbital foramen associated with a well-depressed and diagonally oriented nasolacrimal region; interparietal bone filiform; well-inflated exoccipitals and mastoids; palate wide and long; incisive foramina typically not reaching the anterior plane of $\mathrm{M} 1$; paired posterolateral palatal pits adjacent to the anterior border of the mesopterygoid fossa; mesopterygoid roof excised by large sphenopalatine vacuities; inflated otic capsules with short Eustachian tubes; upper incisors orthodont; molars brachyodont with opposing main cusps; M1 trilophodont with fan-shaped procingulum anteriorly indented by a shallow anteromedian flexus; M2 bilophodont with area of the proto- and paracone clearly broader than that of the hypo- and metacone; M3 reduced and cylindrical in outline; $M 3 / \mathrm{m} 3$ with a single root; mandible gracile with lower border moderately straight, shallow diastema, and mental foramen large and clearly labially positioned; stomach unilocular and hemiglandular.

Description Small sigmodontine with a fusiform body (Figure 2). Ears very reduced and extremely thin, internally and externally covered by long hairs, with a noticeable pure white tuft, which originates inside the pinna notch and surpasses its outer margin. Eyes of medium size (maximum diameter $2.7 \mathrm{~mm}$ in CNP 1). Numerous mystacial vibrissae (15 per side), some totally dark, some totally white, and some basally black and distally whitish. Largest vibrissae (ca. $30 \mathrm{~mm}$ ) posteriorly surpass the auricular pinna margin. Nose covered by dark hairs conforming a "leather button" (Pearson 1984: 234). Dorsal pelage dense, soft, but not long (mid-dorsum hairs ca. 7-8 $\mathrm{mm}$ in length); ventral pelage soft. Lanceolate scale pattern on guard hairs; medullar cells arranged in two parallel rows (see also Chehébar and Martín 1989). Dorsal head and body coloration with agouti effect, produced by almost entirely gray hairs with ochraceous tip; belly coloration gray cream to white, produced by hairs that are basally gray and distally white; lateral line of contact between back and belly marked by hairs with distal half orange. Bright orange spots on rostrum sides. Tail bicolor, moderately haired, proximal hairs ca. $10 \mathrm{~mm}$, short distal tuft; three hairs per scale, each covering three scales in length (dorsal middle region). Manus well covered dorsally with whitish orange hairs; carpal vibrissae shorter than claws, the latter ca. $4 \mathrm{~mm}$ in length, powerful, transversally compressed and ventrally ridged except for the distal third tip. Six palmar pads with naked surface; ungual pads rounded. Hind foot short and broad, with an inner and outer fringe of stiff hairs well extended beyond the plantar surface (Figure 3); bicolored, from ankle to middle portion of metatarsal region washed orange and whitish from this point to the end of the fingers; posterior claws short (ca. $1.6 \mathrm{~mm}$ ) ventrally opened. Six naked plantar pads with smooth surfaces, hypothenar large, first and fourth larger than the second and third.

Skull moderately robust with shortened rostrum, broad interorbital region, well-rounded braincase, expanded zygomatic arches, and flat dorsal profile (Figure 4). The nasals are long, covering most of the rostrum, anteriorly divergent with maximum width just posterior to the anterior end (Figure 5A); in old adult individuals the anterior third of the nasals are noticeably upturned. Nasals and premaxillae surpass the anterior incisive face, appearing "trumpet-like" in lateral view (Figure 5B). In addition, a moderately developed gnathic process is present. The nasofrontal suture is $\mathrm{V}$-shaped and located posteriorly to the plane defined by lacrimal bones (Figure $5 \mathrm{~A}$ ); the premaxilla-frontal suture is well denticulated. Zygomatic notches are inconspicuous, in line with the near absence of an upper free border in the zygomatic plates (Figure 5B). The lacrimal bones are small. Interorbital region with amphoral or "hour-glass shaped" form and frontal sinuses well inflated, frontal external borders squared but not ridged, and coronal suture nearly straight with sharp contacts with parietal bones. Interparietal bone filiform (Figure $5 \mathrm{C}$ ). In the dorsal view of the braincase, large portions of squamosal and occipital bones are evident. Parietal or lambdoidal crests inconspicuous. Occipital region with well-inflated exoccipitals. Rostrum in lateral view with premaxillo-maxillary suture partially arched and welldeveloped nasolacrimal foramen. Infraorbital foramen broad and connected with a depressed diagonally oriented nasolacrimal region; a medium-size circular foramen is present on the rostral process of the premaxilla closely or directly opening on the premaxillo-maxillary suture (Figure 5B); this foramen, topographically associated with nasolacrimal structures, is also present in other 


\section{AUTHORS' PERSONAL DOCUMENT}

278 U.F.J. Pardiñas et al.: New data on Patagonian long-clawed Notiomys

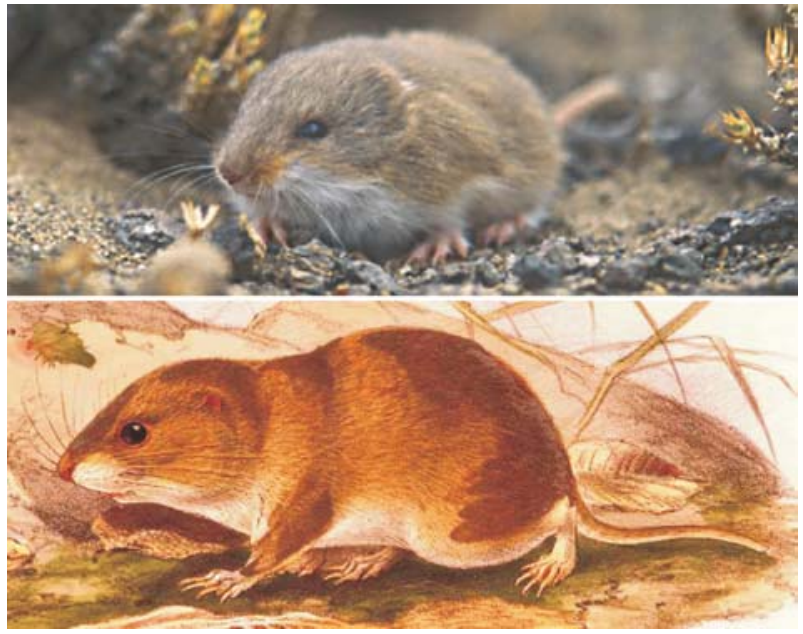

Figure 2 External aspect of Notiomys edwardsii. Above, an individual photographed alive in the area of Cerro El Puma (Santa Cruz, Argentina); note the white tuft of hair in the ear, a trait unique among Patagonian sigmodontines. Below, the original drawing included in Milne-Edwards (1890: Plate 3, Figure 1).

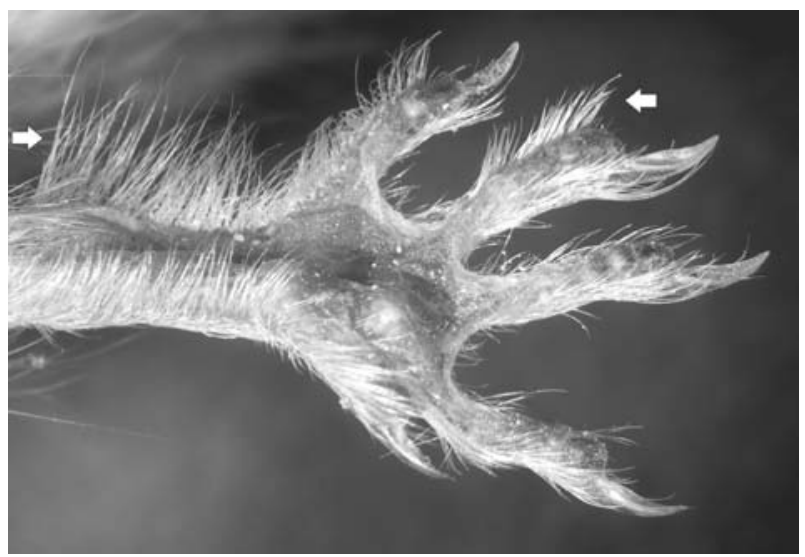

Figure 3 Ventral surface of the right foot of Notiomys edwardsii (CNP 1) showing conspicuous inner and outer fringes of hairs (arrows); also note the ventral opening of the claws.

Abrotrichini (e.g., Abrothrix, Chelemys, Geoxus) and some Akodontini (e.g., Akodon spegazzinii; see Blaustein et al. 1992, where it is referred to as the "preorbital foramen II"), but in Notiomys it is well developed and consistent (visible with the naked eye). Zygomatic plate tall and narrow, with parallel sides and no upper border. Zygomatic plate inclined nearly $45^{\circ}$ with respect to sagittal plane (Figure 5D). Inconspicuous area of insertion of masseter superficialis in the anterior portion of zygomatic plate base. Zygomatic arches delicate, with jugal well developed. Temporal region with strong participation of occipital bone; lateral projection of parietal squared in outline and well developed. Mastoid well inflated, producing the emergence of a squared lower edge; mastoid process well developed and next to large paraoccipital process. Hamular process weak and curved distally on the mastoid promontory of the otic capsule (Figure 5E). Tegmen tympani well developed, attached to squamosal ridge. Postglenoid foramen well developed but subsquamosal fenestra reduced. Auditive meatus large; malleus with an enlarged orbicular process. Incisive foramen

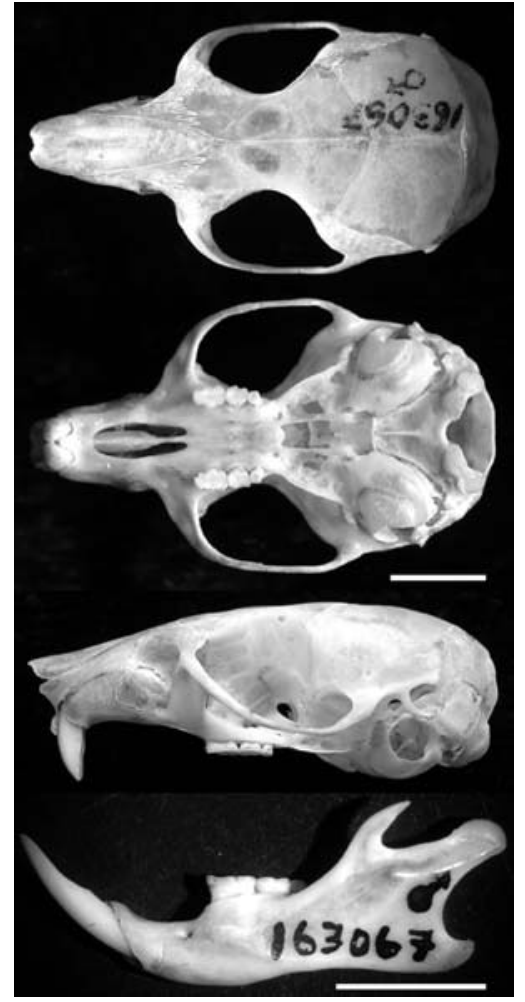

Figure 4 Notiomys edwardsii (MVZ 163067): top to bottom, skull in dorsal, ventral, and lateral views, and left mandible in labial view. Scale bars represent $5 \mathrm{~mm}$.

short and broad, with posterior end typically not reaching the plane defined by the anterior face of M1 (a moderate variation of this trait appears to be ontogenetically related; Figure 5F). Palate broad and long (sensu Hershkovitz 1962), flat, with minute to very large paired posterolateral palatal pits located near the anterior border of the mesopterygoid fossa. The latter fossa is narrow and parallel-sided with a medium palatine process moderately developed on its anterior border. Roof of mesopterygoid region with large sphenopalatine vacuities. Parapterygoid fossae broader than mesopterygoid fossa, flat, with evident fontanels and posteriorly well ossified to contact otic capsules (Figure 5G). Presphenoid short and broad. Ectotympanic bullae large and well inflated with short Eustachian tubes; pteriotic totally covered in dorsal view (Figure $5 \mathrm{H}$ ). Carotid canal only visible in internal lateral view due to ectotympanic development; stapedial foramen well developed, as is the petrotympanic fissure. Large foramen magnum posteriorly located. Alisphenoid strut absent, foramen ovale confluent with alisphenoid canal; a tunnel for secondary arterial connection between internal carotid and orbital-maxillary circulation is present in some individuals (e.g., MVZ 163067); trough for masticatory-buccinator nerve broad but very shallow; squamosal-alisphenoid groove clearly visible with a medial perforation, leads anteriorly to a medium sphenofrontal foramen (Figure 5I). Mandible gracile, with the lower border moderately straight (Figure 4). Lower diastema shallow with the anterior-most point surpassing upwards the alveolar plane. Mental foramen large and located on the base of the diastema, scarcely visible from dorsal view. Masseteric crest moderately developed; its inferior ridge 


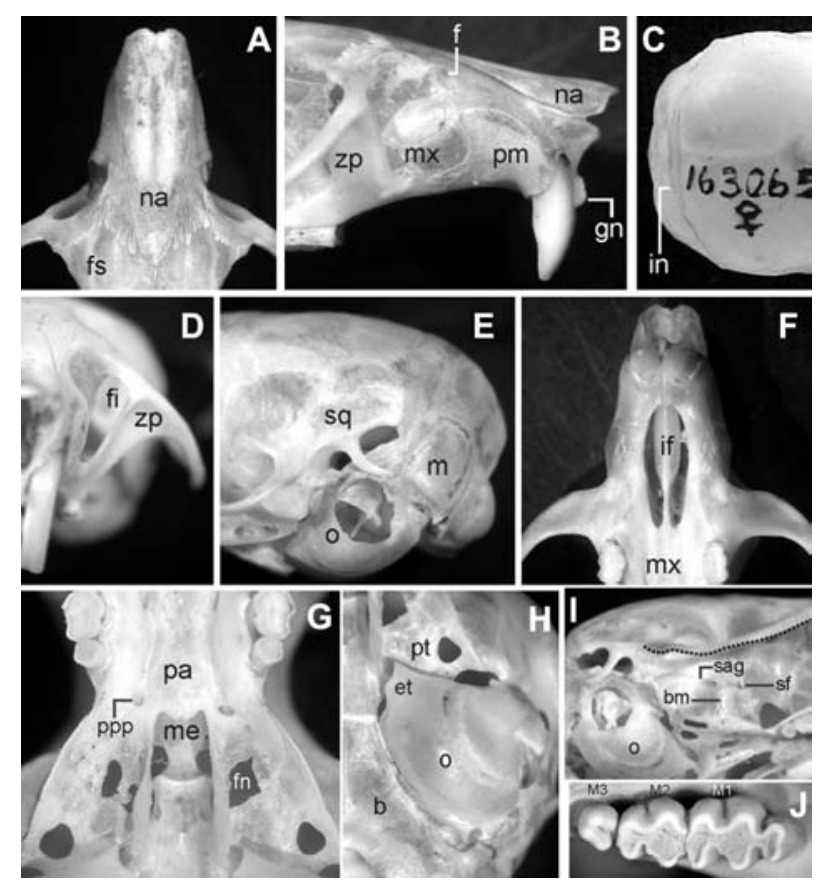

Figure 5 Craniodental morphological details of Notiomys edwardsii (MVZ 163067, except as noted). (A) Rostrum in dorsal view showing inconspicuous zygomatic notches and well-inflated frontal sinuses [fs]. (B) Rostrum in lateral view showing the absence of an upper free border in the zygomatic plate, the moderately arched premaxillo [pm]-maxillary [mx] suture, nasalpremaxillary forward projection, circular foramen on the rostral process of the premaxilla [f], and gnathic process [gn]. (C) Partial braincase in dorsal view showing reduced interparietal [in] bone (MVZ 163065). (D) Skull in frontal view showing the wide infraorbital foramen [fi] and the inclination of the zygomatic plate [zp]. (E) Temporal region in lateral view showing the well-inflated mastoid $[\mathrm{m}]$. (F) Rostrum in ventral view showing anterior extension of the nasal bones and the short incisive foramina [if]. (G) Posterior palatal region showing mesopterygoid fossa [me] morphology and large sphenopalatine vacuities. (H) Otic capsule [o] with very short Eustachian tube [et] and largely ossified parapterygoid plate [pt]. (I) Carotid circulatory pattern illustrated by osteological features. (J) Occlusal view of the left upper toothrow in a young individual (MVZ 163065); note the asymmetry between the anterior and posterior lobes of M2. b, basioccipital; $\mathrm{bm}$, trough for masticatory-buccinator nerve; fn, fontanel; na, nasal; pa, palatine; ppp, posterolateral palatal pits; sag, squamosal-alisphenoid groove; sf, sphenofrontal foramen; sq, squamosal.

meets with the upper ridge, forming a unique crest to the level of the mental foramen. Coronoid process robust and well curved posteriorly, higher than condyloid process, producing a well-excavated sigmoid notch. Angular process broad and shorter with respect to the condyle, producing a lunar notch moderately excised but oblique in profile. Incisor capsule projection medium in size, lying below the coronoid process. Conspicuous retromolar fossa with a medium foramen. Dental foramen large and located over the milohyoid line between coronoid and condyloid processes.

Upper incisors robust and orthodont (Figure 5B); dentine fissure straight (sensu Steppan 1995). Molars brachyodont with some tendency to mesodonty (Figure 5J). Coronal topography bilevel, terraced on the lingual side and crested (in juvenile specimens) to planate (in adults) on the labial side; main cusps arranged in opposite pattern. M1 trilophodont; procingulum fan-shaped and slightly compressed transversally with shallow but consistently present anteromedian flexus; anteroflexusparastile absent; proto- and paraflexus subequal and transversal in orientation; their internal ends meet, producing an anterior mure medially located; para- and protocone subequal in size; paracone coalesces with reduced mesoloph; short but broad hypoflexus; metacone anterior-posteriorly compressed, labially projected; short but present posteroloph directed posteriorly. M2 bilophodont with short anteroloph directed forward, paraflexus almost obsolete, as are the hypo- and mesoflexus; area of the proto- and paracone clearly broader than that of the hypo- and metacone; short posteroloph directed posteriorly. M3 reduced and cylindrical in outline, occlusal details typically missing due to wear; mesofosetus present in young individuals (e.g., CNP 1). Lower molars more crested than upper ones. In $\mathrm{m} 1$ the procingulum is sub-squared in outline with a marked anteromedium flexus, producing two subequal conules; anterior murid medially located; proto- and hypoconid anteriorposteriorly compressed; broad hypoflexid, bulbous metaconid, lingually projecting entoconid coalescent with a reduced mesolophid; posterolophid well developed and directed anteriorly. $\mathrm{m} 2$ similar in shape to $\mathrm{m} 1$, but wider, without evidence of anterolophid. $\mathrm{m} 3$ reduced and bilophodont, with clear transverse compression of the posterior lobe.

Molar roots (partially inferred from alveolar pattern): M1 with two large and circular roots, one anterior and one posterior, the former occasionally divided in two, and conspicuous inter-root space densely foraminated, where a small accessory labial root may be present (under paracone); M2 with three roots, one lingual elliptical in outline and two labials that are subequal and circular; M3 with a single circular root; $\mathrm{m} 1$ with two large roots (anterior and posterior) located along the midline of the tooth, and one reduced root in the labial side; $\mathrm{m} 2$ with two roots (anterior and posterior); $\mathrm{m} 3$ with a single circular root.

Vertebral count (on CNP 1) indicates 13 thoracic, six lumbar, and 18 caudal vertebrae, and 13 ribs (three free); the same numbers were reported by Steppan (1995) based on specimen MVZ 163065.

Stomach morphology unilocular and hemiglandular (Figure 6), typical of many Sigmodontinae (Carleton 1973). The antrum, which is covered by glandular epithelium, is larger than the corpus, which in turns is mostly covered by cornified epithelium. The glandular epithelium from the antrum extends to the corpus and surpasses to the left of the orifice of the esophagus. Carleton (1973) described two gross morphologies among sigmodontines with a unilocular-hemiglandular stomach. The type reported here for Notiomys, in which the glandular epithelium covers a small area of the corpus, is also present in Geoxus and Pearsonomys (Carleton 1973; D’Elía et al. 2006), which form a clade sister to Notiomys in phylogenetic analyses (Smith and Patton 1999; D'Elía et al. 2006). Abrothrix has a unilocular-hemiglandular type, in which the glandular epithelium covers a slightly smaller 


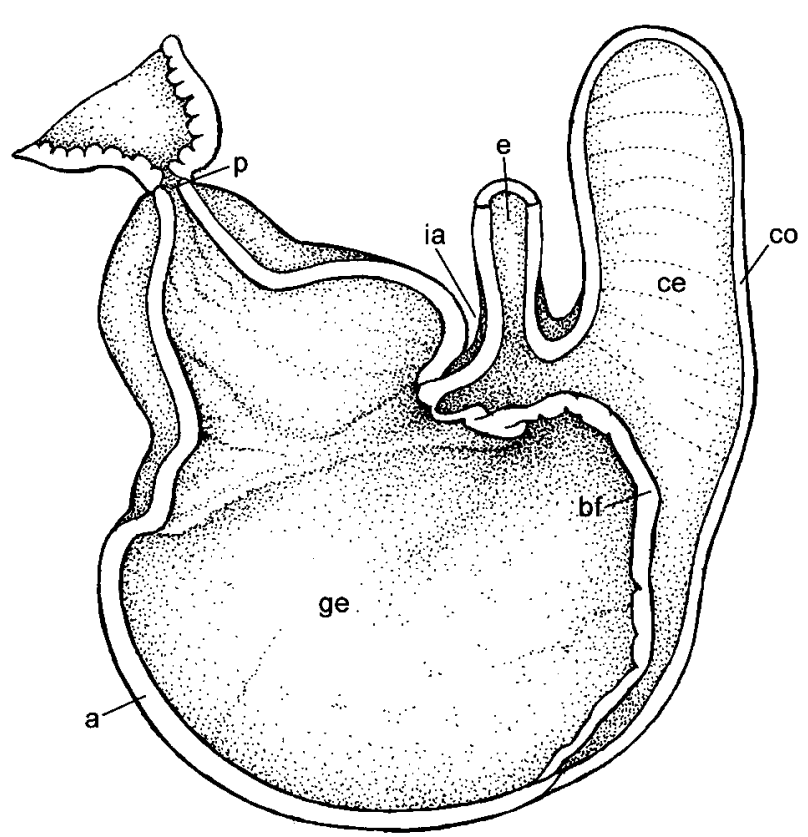

Figure 6 Stomach morphology in Notiomys edwardsii: crosssection based on CNP 1. a, antrum; bf, bordering fold; c, corpus; ce, cornified squamous epithelium; e, esophagus; ge, glandular epithelium; ia, incisura angularis; p, pylorus.

area of the stomach (Carleton 1973). The stomach morphology of Chelemys remains unknown.

Other traits of the soft anatomy (such as penis morphology and gall bladder presence/absence) of $N$. edwardsii remain unknown. The same is true for karyological data, with this being the only genus of Abrotrichini for which this information is lacking.

Measurements External measurements (in $\mathrm{mm}$ ) for the few available complete adult specimens (BM Piedra Clavada, LIEB M-681, MVZ 163065-163067, see Thomas 1929, Pearson 1984, Martin and Archangelsky 2004) provide the following mean and standard deviation values: total length, $129.9 \pm 6.95 \quad(n=5)$; tail length, $41.9 \pm 2.83(n=5)$; hind foot (with claw), 19.1 $\pm 1.24(n=5)$; ear length, 7.4 $\pm 0.82(n=5)$; and weight (in g), $21.3 \pm 3.33$ $(n=3)$. Values for a young specimen (CNP 1) are: 115, 35, 19, 7 and 17, respectively. Craniodental measurements are provided in Table 2.

Morphological variation A consistent geographically structured pattern of variation was observed for the size of paired posterolateral palatal pits (ppp; Figure 7). Samples (localities \#41, 44-46; Table 1) south of Río Deseado (ca. $46^{\circ} 45^{\prime} \mathrm{S}$ ) have large to very large ppp, in some cases with internal subdivisions, whereas samples north of Río Deseado (localities \#1, 2, 5, 8-10, 14, 17-19, 23-27; Table 1) show small to minute or even absent ppp. In addition, although comparisons of external traits are clearly limited by the small sample sizes, individuals from southern populations appear to be more distinctly bicolored, including more pure white on the belly and dorsal surface of the manus and pes than those from northern populations, which are generally characterized by gray-cream ventral coloration. One-way ANOVA and
Tukey tests performed on craniodental measurements of comparable samples (Table 2) revealed significant differences between southern (Santa Cruz) and northern (Somuncurá) populations in zygomatic plate length and both mandibular and maxillary molar alveolar lengths.

\section{Genetic variation and genealogy of Notiomys edward-} sii haplotypes Partial cyt b gene sequences are available for three specimens of $N$. edwardsii captured at different localities. Each specimen showed a different haplotype. Haplotypes recovered in Campo Anexo Pilcaniyeu (locality \#1) and Estancia Laguna Manantiales (\#42), some $760 \mathrm{~km}$ apart, are $0.64 \%$ divergent. The haplotype recovered in Laguna Blanca (\#8) diverges $0.75 \%$ from that of Pilcaniyeu $(300 \mathrm{~km})$ and $0.74 \%$ from the specimen from Manantiales $(700 \mathrm{~km})$. The genealogical analysis recovered three shortest trees of 201 steps $(\mathrm{Cl}=0.920 ; \mathrm{Rl}=0.853)$, consensus of which (data not shown) shows a highly supported $(B S=100) N$. edwardsii clade in which haplotypes from Laguna Blanca (\#8) and Pilcaniyeu (\#1) are sisters to each other $(B S=75)$.

Fossil record Craniodental remains of Notiomys edwardsii were recovered in four Holocene deposits in Patagonia (Table 1; Figure 1). In the Watkins cave sequence, which covers approximately the last 1000 years, $N$. edwardsii is recorded at high frequencies in all stratigraphical levels. The same is true for the Talagapa sequence and Los Altares profile. Both the Los Altares profile and Epullán Grande cave are outstanding for $N$. edwardsii because they fall in areas where this rodent is not currently found (Figure 1). At the former site, $N$. edwardsii is present from lower levels (dated approx. 2200 years) to upper levels ( $<100$ years), suggesting very recent local extinction for the species. The case of Epullán Grande cave is somewhat different; a single $N$. edwardsii was recorded in levels dated as $7060 \pm 90$ radiocarbon years before the present (Crivelli Montero et al. 1996). Taphonomically, microvertebrate assemblages at all these sites were mainly produced by the raptor activities of owls (Pardiñas 1999).

Reproductive data Almost nothing is known about the reproduction of Notiomys edwardsii. A young female (CNP 1) with an imperforate vagina was recorded at the end of the summer season (March).

Natural history Hershkovitz (1966) discussed the degree of fossoriality reached by sigmodontine rodents. He noted two morphologic extremes in this tendency, one convergent with moles (exemplified by Blarinomys within sigmodontines) and the other with gophers (exemplified by Kunsia). Notiomys has a morphologic bauplan that was assumed to be indicative of a fossorial or semifossorial habit (Pearson 1984) and appears to be in line with mole-like adaptations. This bauplan includes, in general terms, reduced eyes and ears, shortened tail, short and velvety pelage, well-developed manus claws, narrow zygomatic plate, rounded and expanded braincase with reduced interparietal bone, wide interorbital region, and reduced molars. In Notiomys, the degree of reduction of the ears is outstanding for sigmodontine 
U.F.J. Pardiñas et al.: New data on Patagonian long-clawed Notiomys 281

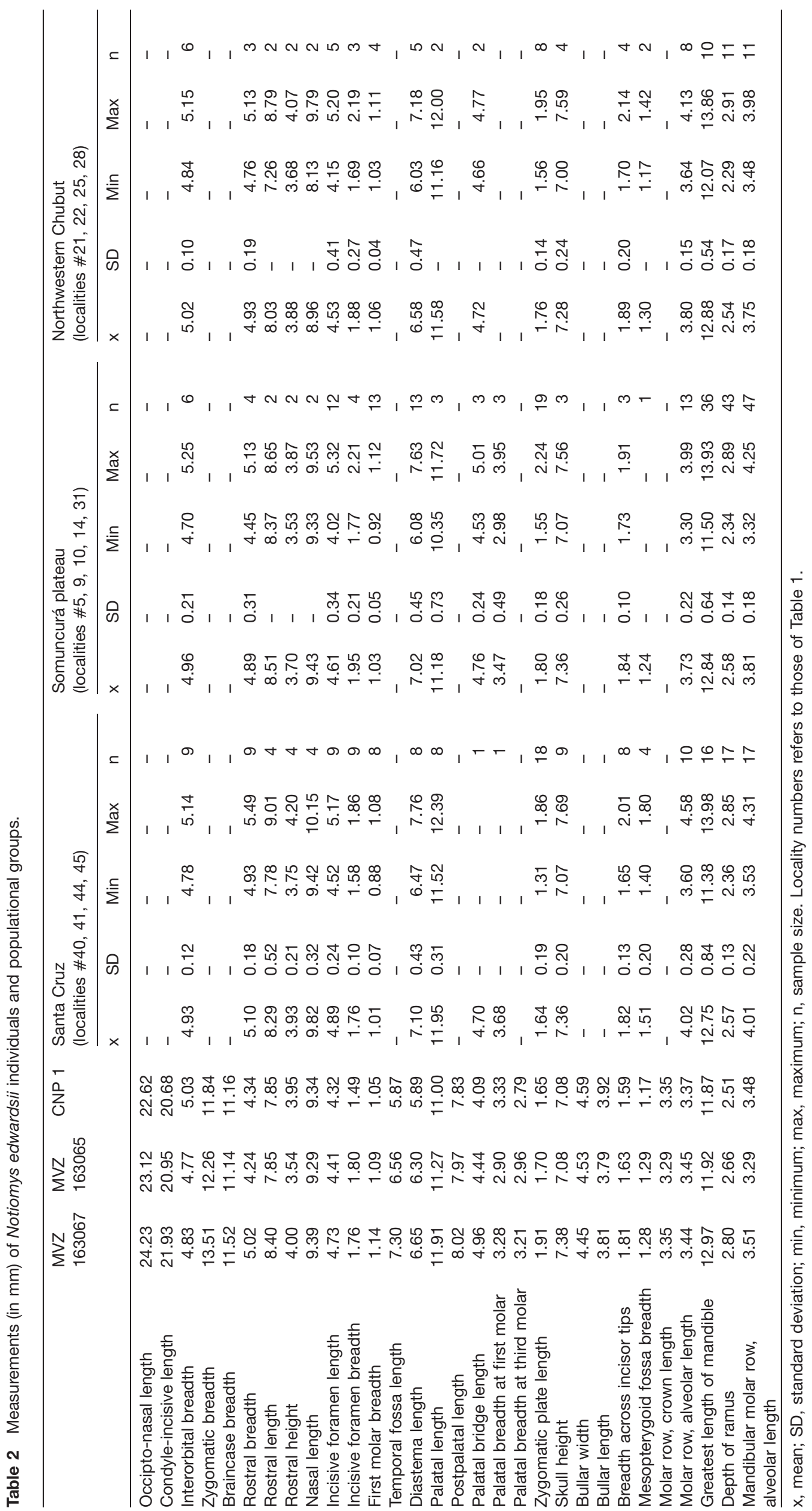




\section{AUTHORS' PERSONAL DOCUMENT}

282 U.F.J. Pardiñas et al.: New data on Patagonian long-clawed Notiomys


Figure 7 Morphological variation in the size of posterolateral palatal pits (indicated by arrows) in Notiomys edwardsii from southern populations. (A-D) N end Lago Cardiel and RN 40 (locality \#44 in Table 1); (E) Laguna del Diez (\#41), and northern populations; (F) Laguna del Paraguay (\#5); (G) Paso del Sapo (\#28); (H) Cerro Castillo (\#17). Abbreviations: mx, maxillary; mf, mesopterygoid fossa; pa, palatine; if, incisive foramina.

rodents, and are even more reduced than those of Blarinomys (Matson and Abrawaya 1977). In addition, the tail length ( $32 \%$ of total length, $n=5)$ places Notiomys among the sigmodontines with the shortest tails. However, the eye of Notiomys is medium in size, suggesting cursoriality to a greater extent than for other mole-like sigmodontines. The same could be said with respect to the intriguing brightness of its pelage and contrasted bicolored pattern. Regrettably, almost nothing is known about the natural history of Notiomys (Pearson 1984) and its potential capacity to make burrows itself, beyond that few individuals were obtained in traps settled in entrances of Ctenomys burrows (Pearson 1984, R. Sage personal communication). Regarding diet, analyses of three stomachs revealed insects, arthropods, and vegetal seed remains (Pearson 1984, Martin and Archangelsky 2004). Some morphological traits, such as the obsolescence of the upper free border in the zygomatic plate, the rapid decay in molar occlusal structures, and the reduction in both size (especially $\mathrm{M} 3 / \mathrm{m} 3$ ) and root number of molar teeth, may be linked to a diet dominated by soft items. In summary, the evidence at hand, although tenuous, appears to indicate that Notiomys is possibly a subfossorial small rodent with a capability to dig in search of invertebrate prey. The adaptations to this niche involve a particular mosaic of morphological traits largely shared with strict fossorial forms; this mosaic has been achieved independently several times (e.g., Blarinomys, Oxymycterus, and Kunsia within Akodontini; D'Elía 2003) within the sigmodontine radiation.

Environments and conservation The 47 contemporary recording localities known for Notiomys edwardsii (Table 1; Figure 1) are strongly associated with two districts of the Phytogeographical Province (PP) Patagónica (sensu León et al. 1998); 12 recording localities fall in the Central district and 33 are in the Occidental district. The remaining two localities are located in the Subandino district (also belonging to the PP Patagónica). Central and Occidental districts include adverse habitats, basaltic plateaus, and hilly landscapes, dominated by poorlydeveloped shrubby steppes (León et al. 1998). Differences in the number of recording localities for both districts may be attributable to asymmetric sample efforts. In contrast, the absence of $N$. edwardsii in contiguous districts, such as Golfo de San Jorge, Ecotone Monte Patagonia and PP del Monte are based on thousands of studied samples (Pardiñas et al. 2003, Pardiñas and Udrizar Sauthier unpublished data). Therefore, it is safe to consider $N$. edwardsii as an endemic species of PP Patagónica.

Numerous collections of Notiomys edwardsii from Somuncurá (localities \#3-13; Table 3), a large basaltic plateau covering ca. $15,000 \mathrm{~km}^{2}$ in north central Patagonia (Croce 1963), invite exploration of microscale hab- 
Table 3 Minimum number of Notiomys edwardsii individuals (and percentage of the total number of individuals of the sample) represented in owl pellets at specific Patagonian localities.

\begin{tabular}{|c|c|c|c|c|}
\hline$\#$ & Locality & N. edwardsii & Total sample & $\%$ \\
\hline 31 & $4 \mathrm{~km}$ S Tres Banderas on RP 11 & 4 & 1312 & 0.3 \\
\hline 26 & Cañadón de la Buitrera & 1 & 242 & 0.4 \\
\hline 30 & Campo de Cretón & 1 & 113 & 0.9 \\
\hline 23 & Fofo Cahuel & 1 & 81 & 1.2 \\
\hline 41 & Laguna del Diez & 1 & 79 & 1.3 \\
\hline 40 & Cueva de las Manos & 2 & 122 & 1.6 \\
\hline 25 & Tres Cuevas & 1 & 57 & 1.8 \\
\hline 21 & 2 km NW Gastre & 1 & 51 & 2.0 \\
\hline 45 & Parador Luz Divina, RN 40 & 2 & 47 & 4.3 \\
\hline 9 & Cerro Corona & 8 & 178 & 4.5 \\
\hline 44 & $\mathrm{~N}$ end Lake Cardiel and RN 40 & 15 & 213 & 7.0 \\
\hline 14 & Subida del Naciente & 18 & 201 & 9.0 \\
\hline 5 & Laguna del Paraguay & 8 & 78 & 10.3 \\
\hline 10 & $3 \mathrm{~km} \mathrm{~N} \mathrm{Cuatro} \mathrm{Cerros} \mathrm{on} \mathrm{route} 60$ & 11 & 101 & 10.9 \\
\hline
\end{tabular}

itat conditions there (Figure 8). The landscape is dominated by a herbaceous steppe ("coironal") composed of Poa ligularis ("coirón poa") and Festuca pallescens ("coirón blanco"), approximately $30 \%$ bare ground (Beeskow et al. 1982), and several basaltic outcrops ringing temporary small lagoons.

In the Argentine Red Book (SAREM 2000), Notiomys edwardsii is categorized as Vulnerable B1 (severely fragmented or known to exist at no more than ten localities). This categorization was correct at that time, because there were only eight recording localities for $N$. edwardsii (Pardiñas and Galliari 1998). The data provided in the present paper clearly indicate that $N$. edwardsii is widely distributed in Patagonia, reaching moderate frequencies at some localities and environments. This suggests that $N$. edwardsii should be categorized as Lower risk/least concern, which is in fact the category proposed earlier, albeit without explanation, by the International Union for Conservation of Nature (IUCN) for the species (Contreras 1996).

Remarks Pearson (1984: 233) suggested a potential connection between Notiomys edwardsii and Hespero-

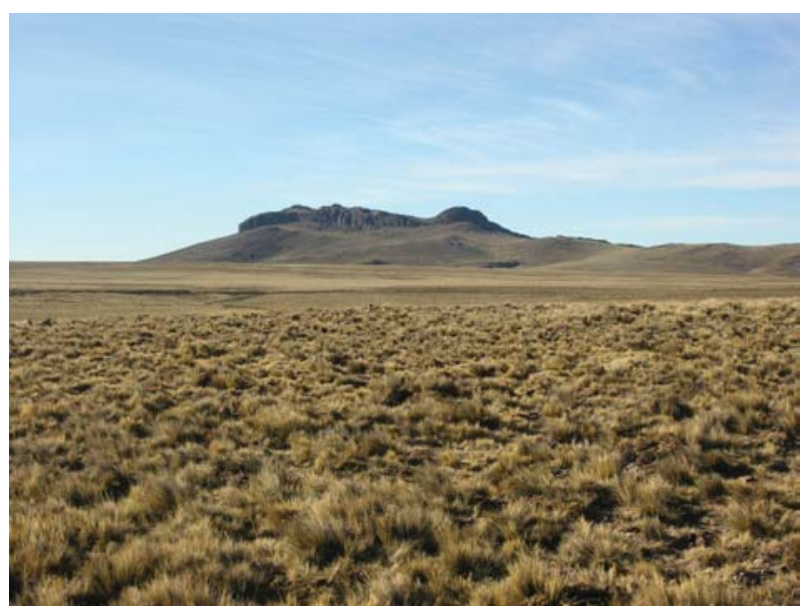

Figure 8 Typical environment occupied by Notiomys edwardsii in the Somuncurá plateau (Río Negro, Argentina). The foreground shows Festuca and Poa grasslands $(>1300 \mathrm{~m})$ that surround Laguna Blanca (second plane, Cerro Corona). mys (Acodon) michaelseni Matschie 1898, a relatively obscure form described on the basis of a specimen from Punta Arenas (southern Chile) and generally allocated under Geoxus. The sole information on michaelseni is, regrettably, that originally published by Matschie (1898); the type appears to be lost. Judging by the pictures and data provided by Matschie (1898: 5-6 and Figure 1), Hesperomys (Acodon) michaelseni does not resemble $N$. edwardsii; michaelseni has a more slanted zygomatic plate, enlarged rostrum, developed interparietal bone, and large manus claws that clearly contrast with the state characters of $N$. edwardsii. All these traits suggest a clear connection with Geoxus, as previously discussed and accepted by Osgood (1925).

\section{Final considerations}

When Osgood (1925) subsumed Chelemys, Geoxus, and Notiomys in a single genus (to which the name Notiomys applied for priority reasons), the generic distinctiveness of $N$. edwardsii was emphatically defended by Thomas (1927: 656): "broad muzzle and interorbital region, squared supraorbital edges, widely splayed anteorbital foramina, narrow, vertical, non-projecting zygomatic plate, short palatal foramina, and minute brachyodont molars make up an ensemble to which one cannot do otherwise than give generic rank." Despite the arguments put forward by Thomas, and in line with the paradigm that dominated sigmodontine systematics during the decades 1940-1970, Notiomys remained broadly defined until the revisionary work of Pearson (1984). Our ongoing studies on Abrotrichini (D'Elía et al. 2006, 2007) highlight that, even when Notiomys sensu lato is monophyletic (i.e., phylogenetically a broad Notiomys sensu Osgood 1925 is supported), in accordance with current classification it is best to keep the genus Notiomys restricted to N. edwardsii alone and to keep using Chelemys, Geoxus, and Pearsonomys as valid genera. In fact, morphological traits displayed by Notiomys are clearly more trenchant than those that distinguish Chelemys, Geoxus, or Pearsonomys.

Departing from most broadly distributed sigmodontines, Notiomys edwardsii does not have any taxon under its synonymy. Moreover, there are no studies assessing 
patterns of geographic variation of this species. The results presented here indicate that across its large distribution (approx. $9^{\circ}$ of latitude), $N$. edwardsii exhibits geographic variation, both at the morphological and genetic level. Morphologically, specimens from south of the Río Deseado are qualitatively and quantitatively different from those of the north. Although available sampling precludes an in-depth comparison, genetic variation appears to follow a similar geographic pattern. Even when divergence values are similar for all haplotype pairs (range $0.64-0.75 \%$ ), the recovered genealogy shows that haplotypes from localities north of the Río Deseado are more closely related to each other than to the haplotype recovered at the single locality south of the river we analyzed. Clearly, considering the few samples available and our poor understanding of intrapopulation variation within $N$. edwardsii, it is premature to hypothesize about the biological meaning, if any, of these patterns of geographic variation. However, these results invite further exploration of species limits among populations of $N$. edwardsii.

\section{Acknowledgements}

Diego Procopio trapped the specimen of Notiomys edwardsii from Laguna Manantiales and generously provided a tissue sample and unpublished data. Marcelo Carrera, Walter Udrizar Sauthier, Joaquín Pardiñas, Alejandra Cuellar, Analía Andrade, Enrique Lessa, and Juan Andrés Martinez assisted us during fieldwork. DNA sequences were gathered by Carolina Abud in Enrique Lessa's lab. Jim Patton (MVZ) and Olga Vaccaro (MACN) loaned specimens of Notiomys. Gabriela Massaferro prepared the distribution map. Gabriel Rojo took the photograph that depicts the external appearance of this mouse and kindly authorized us to reproduce it here. Laura Gelari and María Cristina Morandi aided in the search of "Santa Cruz" historical data. Douglas Kelt, acting as a reviewer, substantially improved the manuscript. This work was funded by CONICET (partially PIP 6179), National Geographic Society (Grant 7813-05), and DIUC (206.113.073-1.0). To the people and institutions mentioned, we extend our deepest gratitude.

\section{References}

Andrade, A. 2008. Mammalia, Rodentia, Cricetidae, Notiomys edwardsii (Thomas, 1890): Distribution extension and geographic distribution map. Check List 4: 33-36.

Andrade, A., P. Teta and C. Panti. 2002. Oferta de presas y composición de la dieta de Tyto alba (Aves: Tytonidae) en el sudoeste de la provincia de Río Negro, Argentina. Hist. Nat. (Corrientes) 1(3): 9-15.

Beeskow, A., C. Beltramone and H. Del Valle. 1982. Relevamiento fisiográfico expeditivo de la meseta de Somuncurá. Centro Nacional Patagónico Contrib. 66: 1-12.

Blaustein, S.A., R.C. Liascovich, L. Apfelbaum, L. Daleffe, R.M. Barquez and O.A. Reig. 1992. Correlates of systematic differentiation between two closely related allopatric populations of the Akodon boliviensis group from NW Argentina (Rodentia: Cricetidae). Z. Säuget. 57: 1-13.

Cabrera, A. 1961. Catálogo de los mamíferos de América del Sur. Parte II. Rev. Mus. Argent. Cs. Nat. "B. Rivadavia" Cs. Zool. 4: 309-732.

Canevari, M., R.A. Chiesa and G. Lingua. 1992. Relevamiento de la meseta de Somuncurá, Pcia. de Río Negro, Argentina. Fundación Vida Silvestre Argent. Bol. Tec. 9: 1-32.
Carleton, M.D. 1973. A survey of gross stomach morphology in New World Cricetine (Rodentia, Muroidea) with comments on functional interpretations. Miscel. Pub. Mus. Zool. Univ. Michigan 146: 1-43.

Carleton, M.D. and G.G. Musser. 1989. Systematic studies of oryzomyine rodents (Muridae, Sigmodontinae): A synopsis of Microryzomys. Bull. Amer. Mus. Nat. Hist. 191: 1-83.

Chehébar, C. and S. Martín. 1989. Guía para el reconocimiento microscópico de los pelos de los mamíferos de la Patagonia. Doñana Acta Vert. 16: 247-291.

Contreras, L. 1996. Notiomys edwardsii. In: IUCN 2007. 2007 IUCN red list of threatened species. www.iucnredlist.org. Accessed 20 November 2007.

Crivelli Montero, E.A., U.F.J. Pardiñas, M. Fernández, M. Bogazzi, A. Chauvin, V. Fernández and M.J. Lezcano. 1996. La Cueva Epullán Grande (provincia del Neuquén, Argentina). Informe de avance. Præhistoria 2: 185-265.

Croce, R. 1963. El sistema del Somuncura. Las Altas Sierras del Somuncura y sus aledaños. Rev. Mus. Argent. Cs. Nat. "B. Rivadavia", Cs. Geol. 6: 303-321.

Cueto, G.R., P. Teta and P. De Carli. 2007. Rodents from southern Patagonian semi-arid steppes (Santa Cruz Province, Argentina). J. Arid Environ. 72: 56-71.

D’Elía, G. 2003. Phylogenetics of Sigmodontinae (Rodentia, Muroidea, Cricetidae), with special reference to the akodont group, and with additional comments on historical biogeography. Cladistics 19: 307-323.

D’Elía, G. and U.F.J. Pardiñas. 2004. Systematics of Argentinean, Paraguayan, and Uruguayan swamp rats of the genus Scapteromys (Rodentia, Cricetidae, Sigmodontinae) J. Mammal. 85: 897-910.

D’Elía, G., A.A. Ojeda, F. Mondaca and M.H. Gallardo. 2006. New data of the long-clawed mouse Pearsonomys annectens (Cricetidae, Sigmodontinae) and additional comments on the distinctiveness of Pearsonomys. Mamm. Biol. 71: 39-51.

D’Elía, G., U.F.J. Pardiñas, P. Teta and J.L. Patton. 2007. Definition and diagnosis of a new tribe of sigmodontine rodents (Cricetidae: Sigmodontinae), and a revised classification of the subfamily. Gayana 71 : 187-194.

Delibes, M., A. Travaini, S. Zapata and F. Palomares. 2003. Alien mammals and the trophic position of the lesser grison (Galictis cuja) in Argentinean Patagonia. Can. J. Zool. 81: 157-162.

Farris, J.S. 1982. The logical basis of phylogenetic analysis. In: (N. Planick and V. Funk, eds.) Advances in cladistics: Proceedings of the 2nd meeting of the Willi Hennig Society. Columbia University Press, New York. pp. 7-36.

Fleuriais, G.E. 1882. Passage de Vénus, Mission de Santa Cruz (Patagonie). Photograph album. American Philosophical Society.

Gyldenstolpe, N. 1932. A manual of Neotropical sigmodont rodents. Kungliga Svenska Vetenskapsakademiens Handlingar 3: 1-164.

Hershkovitz, P. 1962. Evolution of Neotropical cricetine rodents (Muridae), with special reference to the Phyllotine group. Field. Zool. 46: 1-524.

Hershkovitz, P. 1966. South American swamp and fossorial rats of the Scapteromyine group (Cricetinae, Muridae) with comments on the glans penis in murid taxonomy. Z. Säuget. 31: $81-149$.

Jayat, J.P., P.E. Ortiz, P. Teta, U.F.J. Pardiñas and G. D’Elía. 2006. Nuevas localidades argentinas para algunos roedores sigmodontinos (Rodentia: Cricetidae). Mast. Neotrop. 13: 51-67.

León R.J.C., D. Bran, M. Collantes, J.M. Paruelo and A. Soriano. 1998. Grandes unidades de vegetación de la Patagonia extra andina. In: (M. Oesterheld, M.R. Aguiar and J.M. Paruelo, eds.) Ecosistemas patagónicos. Ecol. Aust. 8: 125-144.

Liascovich, R.C., R.M. Barquez and O.A. Reig. 1989. A karyological and morphological reassessment of Akodon (Abrothrix) illuteus Thomas. J. Mamm. 70: 386-391.

Lozada, M., A. Monjeau, K. Heinemann, N. Guthmann and E.C. Birney. 1996. Abrothrix xanthorhinus. Mamm. Species 540: 1-6.

Martial, L.F. 1888. Histoire du voyage. Mission Scientifique du 
Cap Horn. 1882-1883. Tome 1. Ministères de la Marine et de l'instruction Publique, Gauthier-Villars et fils, Paris.

Martin, G.M. and M. Archangelsky. 2004. Aportes al conocimiento de Notiomys edwardsii (Thomas, 1890) en el noroeste del Chubut, Argentina. Mast. Neotrop. 11: 91-94.

Matschie, P. 1898. Säugethiere. Hamburger Magalhaensische Sammelreise. L. Friederichsen \& Co., Hamburg 1: 1-29.

Matson, J. and J.P. Abrawaya. 1977. Blarinomys breviceps. Mamm. Species 74: 1-3.

Milne-Edwards, A. 1890. Mammifères. Mission Scientifique du Cap Horn 1882-1883. Tome VI. Zoologie. Primière partie. Ministères de la Marine et de l'instruction Publique, GauthierVillars et fils, Paris. pp. 3-32.

Mouchez, E. 1882. Observation du Passage de Vénus dans la République Argentine. C. R. Hebd. Séances Acad. Sci. 95: 1182-1184.

Moyano, M.C. 1948. Carlos Moyano el explorador de la Patagonia. Librería "El Ateneo" Editorial, Buenos Aires. 310 pp.

Musser, G.M. and M.D. Carleton. 2005. Superfamily Muroidea. In: (D.E. Wilson and D.M. Reeder, eds.) Mammal species of the world: A taxonomic and geographic reference, 3rd ed. Johns Hopkins University Press, Baltimore, MD. pp. 8941531.

Osgood, W.H. 1925. The long-clawed South American rodents of the genus Notiomys. Field Mus. Nat. Hist., Zool. Ser. 12: 113-125.

Pardiñas, U.F.J. 1999. Los roedores muroideos del Pleistoceno tardío-Holoceno en la Región Pampeana (sector Este) y Patagonia (República Argentina): aspectos taxonómicos, importancia bioestratigráfica y significación paleoambiental. Ph.D. thesis, Facultad de Ciencias Naturales y Museo, Universidad Nacional de La Plata.

Pardiñas, U.F.J. and C.A. Galliari. 1998. La distribución del ratón topo Notiomys edwardsii (Mammalia: Muridae). Neotrópica 44: 123-124.

Pardiñas, U.F.J. and P. Teta. 2007. Micromamíferos del sector oriental de la Altiplanicie del Somuncurá (Río Negro, Argentina). Mast. Neotrop. 14: 271-278.

Pardiñas, U.F.J., P. Teta, S. Cirignoli and D.H. Podestá. 2003. Micromamíferos (Didelphimorphia y Rodentia) de Norpatagonia Extra Andina, Argentina: taxonomía alfa y biogeografia. Mast. Neotrop. 10: 69-113.

Patterson, B.D. 1992. A new genus and species of long-clawed mouse (Rodentia: Muridae) from temperate rainforests of Chile. Zool. J. Linn. Soc. 106: 127-145.

Pearson, O.P. 1984. Taxonomy and natural history of some fossorial rodents of Patagonia, southern Argentina. J. Zool. (Lond.) 202: 225-237.
Pearson, O.P. 1995. Annotated keys for identifying small mammals living in or near Nahuel Huapi National Park or Lanín National Park, southern Argentina. Mast. Neotrop. 2: 99-148.

Reig, O.A. 1977. A proposed unified nomenclature for the enamelled components of the molar teeth of the Cricetidae (Rodentia). J. Zool. (Lond.) 181: 227-241.

Reig, O.A. 1987. An assessment of the systematics and evolution of the Akodontini, with the description of new fossil species of Akodon (Cricetidae, Sigmodontinae). In: (B.D. Patterson and R.M. Timm, eds.) Studies in neotropical mammalogy. Field. Zool. 39: 347-399.

SAREM. 2000. Libro rojo de los mamíferos amenazados de la Argentina. Sociedad Argentina para el Estudio de los Mamíferos, Mendoza. $106 \mathrm{pp}$.

Smith, M.F. and J.L. Patton. 1999. Phylogenetic relationships and the radiation of sigmodontine rodents in South America: Evidence from cytochrome b. J. Mamm. Evol. 6: 89-128.

Smith, M.F., D.A. Kelt and J.L. Patton. 2001. Testing models of diversification in mice in the Abrothrix olivaceus/xanthorhinus complex in Chile and Argentina. Mol. Ecol. 10: 397-405.

Spotorno, O.A. 1992. Parallel evolution and ontogeny of simple penis among new world cricetid rodents. J. Mammal. 73: 504-514.

Steppan, S.J. 1995. Revision of the tribe Phyllotini (Rodentia: Sigmodontinae), with a phylogenetic hypothesis for the Sigmodontinae. Field. Zool. 80: 1-112.

Swofford, D.L. 2000. PAUP*. Phylogenetic analysis using parsimony ("and other methods). Version 4.0b4a. Sinauer Associates, Sunderland, MA, USA.

Teta, P. and A. Andrade. 2002. Micromamíferos depredados por Tyto alba (Aves, Tytonidae) en las Sierras de Talagapa (provincia de Chubut, Argentina). Neotrópica 48: 88-90.

Teta, P., A. Andrade and U.F.J. Pardiñas. 2002. Novedosos registros de roedores sigmodontinos (Rodentia: Muridae) en la Patagonia central argentina. Mast. Neotrop. 9: 78-89.

Thomas, O. 1919. On small mammals collected by Sr. E. Budin in North-western Patagonia. Ann. Mag. Nat. Hist. (Lond.) Ser. 9 3: 199-212.

Thomas, O. 1927. On a further collection of mammals made by Sr. E. Budin in Neuquen, Patagonia. Ann. Mag. Nat. Hist. (Lond.) Ser. 9 19: 650-658.

Thomas, O. 1929. The mammals of Señor Budin's Patagonian expedition, 1927-28. Ann. Mag. Nat. Hist. (Lond.) Ser. 10 4: $35-45$.

Tribe, C.J. 1996. The Neotropical rodent genus Rhipidomys (Cricetidae: Sigmodontinae): a taxonomic revision. Ph.D. dissertation, University College, London. 